Prepared as part of the National Water-Quality Assessment Program, Source Water-Quality Assessment

\title{
Organic Compounds in Truckee River Water Used for Public Supply near Reno, Nevada, 2002-05
}

Organic compounds studied in this U.S. Geological Survey (USGS) assessment generally are man-made, including, in part, pesticides, solvents, gasoline hydrocarbons, personal care and domestic-use products, and refrigerants and propellants. Of 258 compounds measured, 28 were detected in at least 1 source water sample collected approximately monthly during 2002-05 at the intake of the Chalk Bluff Treatment Plant, on the Truckee River upstream of Reno, Nevada. The diversity of compounds detected indicate various sources and uses (including wastewater discharge, industrial, agricultural, domestic, and others) and different pathways (including point sources from treated wastewater outfalls upstream of the sampling location, overland runoff, and groundwater discharge) to drinking-water supply intakes. Three compounds were detected in more than 20 percent of the source-water intake samples at low concentrations (less than 0.1 microgram per liter), including caffeine, p-cresol (a wood preservative), and toluene (a gasoline hydrocarbon). Sixteen of the 28 compounds detected in source water also were detected in finished water (after treatment, but prior to distribution; 2004-05). Additionally, two disinfection by-products not detected in source water, bromodichloromethane and dibromochloromethane, were detected in all finished water samples. Two detected compounds, cholesterol and 3-beta-coprostanol, are among five naturally occurring biochemicals analyzed in this study. Concentrations for all detected compounds in source and finished water generally were less than 0.1 microgram per liter and always less than human-health benchmarks, which are available for about one-half of the compounds. Seven compounds (toluene, chloroform, bromodichloromethane, dibromodichloromethane, bisphenol A, cholesterol, and 3-beta-coprostanol) were measured at concentrations greater than 0.1 microgram per liter. On the basis of this screening-level assessment, adverse effects to human health are expected to be negligible (subject to limitations of available human-health benchmarks).

\section{Introduction}

An investigation by the National WaterQuality Assessment (NAWQA) Program of the USGS characterizes the occurrence of 258 organic compounds in source water (defined as stream water collected at a surface-water intake prior to water treatment) and finished water (defined as water that has passed through treatment processes but prior to distribution) at the Truckee Meadows Water Authority (TMWA) Chalk Bluff Treatment Plant. This water treatment plant is one of several community water systems that use the Truckee River as its sole source of water supply upstream of Reno, Nevada (fig. 1). The Truckee River flows from alpine Lake Tahoe (altitude about 6,200 ft) for $116 \mathrm{mi}$ until it discharges into Pyramid Lake (altitude about 3,800 ft), a desert terminus lake. The Sierra Pacific Railroad and Interstate 80 run parallel to the Truckee River throughout much of the study area (fig. 1); both provide potential sources of contamination to the Truckee River. Samples were collected approximately monthly from the Truckee River during 2002-05 using USGS collection methods (USGS, 1997-2006), and included 25 source water (2002-05; some analyses are for only 24 samples) and 8 finished water (2004-05) samples. Samples were collected during high winter-spring flows (maximum mean daily flow of 1,340 cubic feet per second during the study period; Truckee River near Mogul stream-gaging site) and

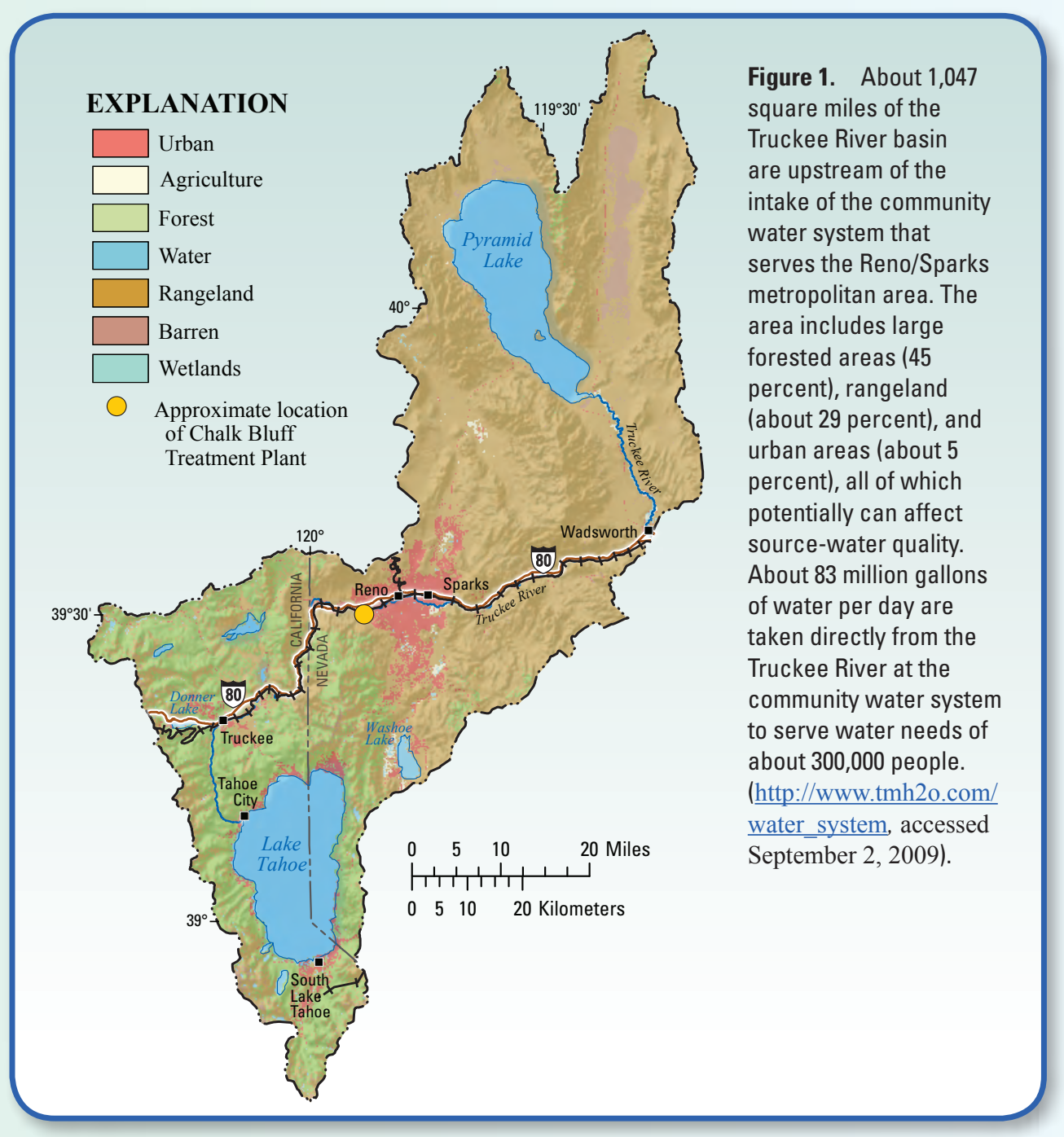


low summer-autumn flows (minimum mean daily flow of 30 cubic feet per second during the study period; Truckee River near Mogul stream-gaging site). Storm events were not specifically targeted during this study. The samples were analyzed by the USGS National Water Quality Laboratory for pesticides and selected pesticide degradates, solvents, gasoline hydrocarbons, disinfection by-products, personal care and domestic-use products, refrigerants and propellants, and other compounds. These data are stored in the USGS National Water Information System (NWIS). Community water systems are required to monitor finished water for compounds regulated under the Safe Drinking Water Act. Most compounds included in this study are not regulated under U.S. Environmental Protection Agency (USEPA) Federal drinking-water standards (U.S. Environmental Protection Agency, 2007a). The Truckee River study is part of an ongoing NAWQA investigation of community water systems across the United States. Additional detailed information and references on the sampling design; methodology, specific compounds monitored, and the national study are described by Carter and others (2007). Further USGS information on water quality in the Truckee River basin is available in a previous NAWQA study (Bevans and others, 1998).

\section{Occurrence of Organic Compounds in Source Water}

Twenty-eight of the 258 compounds analyzed for this study were detected in at least 1 source-water sample. These compounds represent many different sources and uses and include pesticides, gasoline hydrocarbons, personal care products, solvents, and other sources and uses. Three compounds were detected in more than 20 percent of the samples: caffeine, $p$-cresol (a wood preservative), and toluene (a gasoline hydrocarbon) at concentrations less than 0.1 microgram per liter $(\mu \mathrm{g} / \mathrm{L})$.

Recent advances in laboratory analytical methods have given scientists the tools to detect a wide variety of contaminants in the environment at low concentrations — often 100 to 1,000 times lower than drinking-water standards (see inset "What 'Detections' May Mean to Human Health"). Twenty-five source-water samples were collected and analyzed for 258 compounds, of which, 28 (11 percent) were detected in at least one sample in this study (table 1). Overall, the compounds detected most frequently in water from the Truckee River generally were among those most commonly detected in ambient stream water across the Nation (Kingsbury and others, 2008). Although 28 compounds were detected in source water samples, most of these compounds were at concentrations of less than $0.1 \mu \mathrm{g} / \mathrm{L}$. For all sourcewater sampled for this study, 230 compounds ( 89 percent) were not detected in any source-water.

Three compounds were detected in more than 20 percent of the source-water samples: caffeine, p-cresol, and toluene. These compounds are used in domestic use products, wood preservatives, and gasoline hydrocarbons, in urban and residential areas in the Truckee River basin and across the Nation (Bevans and others, 1998; Kingsbury and others, 2008). Their occurrence likely is attributed to runoff from the I- 80 corridor, which includes a railroad as well as heavy traffic. The close proximity of railroad tracks and I- 80 along the Truckee River for many miles upstream of the Chalk Bluff intake makes creosote treated railroad ties and treated posts for guardrails a likely source of p-cresol and automobile, truck, and train traffic a likely source of toluene. Kingsbury and others (2008) identified similar sources for these compounds, but their study also included groundwater discharge and (or) treated wastewater discharge from upstream municipalities as other potential sources of these compounds, particularly for caffeine.

\section{What "Detections" May Mean to Human Health}

The analytical methods used in this study have low detection levelstypically 100 to 1,000 times lower than State and Federal standards and guidelines for protecting water quality. Detections, therefore, do not necessarily indicate a concern to human health but rather help to identify the environmental presence of a wide variety of chemicals not commonly monitored in water resources and to track changes in their occurrence and concentrations over time. These findings complement ongoing drinking-water monitoring required by Federal, State, and local programs, which focus primarily on post-treatment compliance monitoring of contaminants regulated by USEPA in drinking water. Many of the compounds analyzed by USGS are not included in other source- and finished-water monitoring programs such as the Unregulated Contaminant Monitoring Regulation (U.S. Environmental Protection Agency, 2007b) and the U.S. Department of Agriculture's Pesticide Data Program (U.S. Department of Agriculture, 2008).

\section{Comparisons Between Source Water and Finished Water}

More than one-half of compounds detected in source water also were detected in finished water, and generally at similar concentrations (except for disinfection by-products), typically less than 0.1 micrograms per liter.

Comparisons between source water and finished water are not intended to characterize treatment efficacy, but to provide a preliminary indication of the potential importance of compounds found in source water to the quality of finished water prior to distribution (see inset "Finished Water Sampling, Water Treatment, and Significance of Comparisons to Source Water").

Sixteen of the 28 ( 57 percent) compounds were detected in both source and finished waters (table 1), and often at similar low-level concentrations. Eight gasoline hydrocarbons were detected in source and finished waters (table 1). Three of the six (50 percent) personal care and domestic use products and two of the four (50 percent) disinfection by-products were detected in source and finished waters (table 1 ). Toluene was detected in 10 of the 25 (40 percent) source-water samples and six of the eight (75 percent) finished-water samples, although concentrations of toluene in source-water samples were all less than 0.1 $\mu \mathrm{g} / \mathrm{L}$ and only one finished water sample had concentrations of toluene greater than $0.1 \mu \mathrm{g} / \mathrm{L}$ (table 2; fig. 2).

Twelve of 28 compounds were detected only in source water. These include all four of the herbicide and herbicide degradates, both of the plant- or animal-derived biochemicals, the wood preservative compound, which was present in one-third of the source-water samples, three of the personal care and domestic use products, and one organic synthesis compound (table 1). All four herbicide and herbicide degradate compounds were detected between December 2002 and March 2003, although finished water sampling did not begin until August 2004, so it is not known if these compounds also would have been detected in the finished water. Processes affecting the occurrence of the plant- and animal-derived biochemicals are not well understood. The wood preservative compound ( $\mathrm{p}$-cresol) may be removed during the water treatment process.

Two compounds, disinfection by-products (bromodichloromethane and dibromochloromethane; tables 1 and 2), were detected only in finished water. The presence of disinfection by-products in finished water is well documented, understood, and regulated, and is an expected outcome of drinking-water disinfection (Krasner and others, 2006). 
Table 1. A total of 30 of 258 organic compounds were detected in source water and (or) finished water samples, near Reno, Nevada, 2002-05. Twenty-eight compounds were detected in source water, and 16 of the 28 compounds also were detected in finished water. Two compounds were detected only in finished water samples. The diversity of compounds indicate various uses-including industrial, agricultural, and domestic - and different pathways — including treated wastewater outfalls upstream of the sampling location, overland runoff, and groundwater discharge_-of the compounds entering drinking-water supplies.

[Black text indicates compounds detected in source and finished water; orange text indicates compounds detected only in source water; blue text indicates compounds detected only in finished water; italics indicates pesticide degradates]

\begin{tabular}{l}
\multicolumn{1}{c}{ Herbicides and herbicide degradates } \\
\hline Atrazine \\
Dacthal \\
Deethyl atrazine (DEA) \\
Diuron
\end{tabular}

Plant- or animal-derived biochemicals

Cholesterol

3-beta-coprostanol

\begin{tabular}{l}
\multicolumn{1}{c}{ Personal care and domestic use products } \\
\hline Caffeine \\
Camphor \\
HHCB (Hexahydrohexamethylcyclopentabenzopyran) \\
d-Limonene \\
Menthol \\
Methyl salicylate \\
\hline \multicolumn{1}{c}{ Manufacturing additives } \\
\hline
\end{tabular}

Bisphenol A

Tris(2-chloroethyl)phosphate

Wood preservative

p-Cresol

\begin{tabular}{l}
\hline \multicolumn{1}{c}{ Gasoline hydrocarbons and oxygenates } \\
\hline Benzene \\
Ethylbenzene \\
Naphthalene \\
o-Xylene \\
Styrene \\
Toluene \\
m- and p-Xylene \\
1,2,4- Trimethylbenzene \\
\hline \multicolumn{1}{c}{ Solvents } \\
\hline Methylene chloride \\
\hline \multicolumn{1}{c}{ Disinfection by-products }
\end{tabular}

Bromoform

Chloroform

Bromodichloromethane

Dibromochloromethane

\begin{tabular}{l}
\hline \multicolumn{2}{c}{ Fumigant-related compound } \\
\hline 1,4-Dichlorobenzene \\
\hline Organic synthesis compounds \\
\hline Carbazol
\end{tabular}

\section{A Closer Look at Gasoline Hydrocarbons and Personal Care and Domestic Use Products}

Detections and concentrations of commonly used gasoline hydrocarbons are relatively similar in source and finished water. Occurrence and concentrations of hydrocarbon compounds differ compound by compound, depending on chemical properties, use, and hydrologic pathways.

Eight paired samples (source and finished water) were collected as part of this study from August 2004 to January 2005. Gasoline hydrocarbons were detected in five source-water samples and three finishedwater samples. Gasoline hydrocarbons are organic compounds that are highly volatile, contain only carbon and hydrogen atoms, and are common ingredients in gasoline and other petroleum products. Benzene, toluene, ethylbenzene, and xylene (BTEX) compounds are among those present in the highest proportions in gasoline (Carter and others, 2007). These compounds may enter surface waters from contaminated groundwater, runoff from roads and parking lots, and directly from watercraft. During sampling by USGS personnel, a petroleum sheen

\section{Finished Water Sampling, Water Treatment, and Significance of Comparisons to Source Water}

The Chalk Bluff Treatment Plant, operated by TMWA, uses conventional water treatment: coagulation/flocculation using aluminum sulfate; sedimentation; filtration through anthracite and sand; and disinfection with chlorine and chloramine. Powdered activated carbon is used occasionally to treat for taste and odor issues during summer months. Finished-water samples were collected at the Chalk Bluff Treatment Plant from August 2004 to January 2005. These samples were collected approximately 4 to 6 hours after collection of source-water samples to account for retention time of the water in the treatment plant (B. Hauk, Chalk Bluff Treatment Plant, oral commun., 2004). Some differences between source- and finished-water quality might be attributable to changes in source-water quality not represented by the finished-water samples because of sample timing and variations in retention time, and potential analytic variability associated with low concentrations at or near laboratory reporting levels (Kingsbury and others, 2008). Some compounds detected in source water possibly were transformed during the treatment process into compounds that were not monitored as part of this study.

The study sampling design and resulting comparisons are not intended to characterize treatment efficacy, but to provide a preliminary indication of the potential importance of compounds detected in source water to the quality of finished water prior to distribution. Generally, the type of treatment used by the Chalk Bluff Treatment Plant is not specifically designed to remove most of the organic compounds monitored in this study. 
Table 2. Seven compounds that were detected in source and (or) finished water had concentrations greater than 0.1 microgram per liter, near Reno, Nevada, 2002-05. None of these concentrations exceeded a human-health benchmark; however, benchmarks are available only for five of the seven compounds included in this table.

[Percent occurrence: Estimated concentrations are used for compounds that have reporting level greater than Maximum Contaminant Level (MCL) of $0.1 \mu \mathrm{g} / \mathrm{L}$. Reporting level: Value shown is higher value of either source or finished water. MCL or HBSL: MCL values in bold. Abbreviations: $\mu \mathrm{g} / \mathrm{L}$, microgram per liter; E, estimated; HBSL, Health-Based Screening Level; THM, trihalomethane; ND, not detected; >, greater than; -, no data]

\begin{tabular}{|c|c|c|c|c|c|c|c|c|}
\hline \multirow{2}{*}{ Name of compound } & \multicolumn{2}{|c|}{$\begin{array}{c}\text { Number of } \\
\text { samples analyzed }\end{array}$} & \multicolumn{2}{|c|}{$\begin{array}{l}\text { Percent occurrence } \\
>0.1 \mu \mathrm{g} / \mathrm{L}\end{array}$} & \multirow{2}{*}{$\begin{array}{c}\text { Reporting } \\
\text { level } \\
(\mu \mathrm{g} / \mathrm{L})\end{array}$} & \multirow{2}{*}{$\begin{array}{l}\text { MCL or } \\
\text { HBSL } \\
(\mu g / L)\end{array}$} & \multicolumn{2}{|c|}{$\begin{array}{c}\text { Maximum concentration } \\
(\mu \mathrm{g} / \mathrm{L})\end{array}$} \\
\hline & $\begin{array}{l}\text { Source } \\
\text { water }\end{array}$ & $\begin{array}{c}\text { Finished } \\
\text { water }\end{array}$ & $\begin{array}{l}\text { Source } \\
\text { water }\end{array}$ & $\begin{array}{l}\text { Finished } \\
\text { water }\end{array}$ & & & $\begin{array}{l}\text { Source } \\
\text { water }\end{array}$ & $\begin{array}{l}\text { Finished } \\
\text { water }\end{array}$ \\
\hline \multicolumn{9}{|c|}{ Gasoline hydrocarbons and oxygenates } \\
\hline Toluene & 25 & 8 & 0 & 75 & 0.05 & 1,000 & ND & 0.180 \\
\hline \multicolumn{9}{|c|}{ Disinfection by-products } \\
\hline Chloroform & 25 & 8 & 0 & 100 & 0.024 & & ND & 16.35 \\
\hline Bromodichloromethane & 25 & 8 & 0 & 100 & 0.048 & 80 total & ND & 4.98 \\
\hline Dibromochloromethane & 25 & 8 & 0 & 100 & 0.18 & THMs $^{1}$ J & ND & 0.975 \\
\hline \multicolumn{9}{|c|}{ Manufacturing additives } \\
\hline Bisphenol A & 24 & 8 & 4 & 0 & 1 & 400 & E0.120 & ND \\
\hline \multicolumn{9}{|c|}{ Plant- or animal-derived biochemicals } \\
\hline Cholesterol & 24 & 8 & 4 & 0 & 2 & - & E0.520 & ND \\
\hline 3-beta-Coprostanol & 24 & 8 & 4 & 0 & 2 & - & E0.250 & ND \\
\hline
\end{tabular}

${ }^{1} \mathrm{MCL}$ of $80 \mu \mathrm{g} / \mathrm{L}$ is for total THMs, including chloroform, bromoform, bromodichloromethane, and dibromochloromethane.



Figure 2. Nine of the 16 compounds detected in source water also were detected in finished water for paired samples, and typically at similar low-level concentrations (from August 2004 to January 2005). Some compounds detected in source water were removed or transformed during treatment and, therefore, were not detected in finished water (data points on horizontal $\mathrm{x}$-axis). Other compounds were detected only in finished water (data points on vertical y-axis). Compounds not identified on the plot include 1,2,4-trimethylbenzene, methylene chloride, ethylbenzene, $\mathrm{m}$ - and $\mathrm{p}$-xylene, styrene, bisphenol A, and d-limonene. Laboratory Reporting Levels range from 0.02 to 2.0 micrograms per liter. (Note: The occurrence of disinfection by-products is not shown in this figure due to high concentration values.) 
was observed at the water intake to the Chalk Bluff Treatment Plant at the time of collection of two paired samples with detected gasoline hydrocarbons. Seven of the eight gasoline hydrocarbons detected in the source water also were detected in the finished water for those two samples. A generator used with equipment to bubble air into the stream water to prevent ice buildup at the intake gates may have been a source of the gasoline hydrocarbons. In a separate paired sample (November 2004), the petroleum hydrocarbon styrene was detected in source and finished waters. One of the most commonly detected compounds associated with gasoline is the oxygenate additive methyl tert-butyl ether (MTBE) (Kingsbury and others, 2008). Despite the detections of eight gasoline hydrocarbons in source and finished waters, no MTBE was detected in samples collected for this study. The presence of BTEX and other gasoline-related volatile organic compounds (VOCs) along with the absence of MTBE in source waters has been observed throughout the United States (Grady, 2002). Additionally, MTBE is banned in the Lake Tahoe basin so the absence of MTBE in samples from the study area is not unexpected.

Six personal care and domestic use products were detected in source water samples. Three of these six compounds also were detected in finished water samples (table 1). Personal care and domestic use products are compounds that are present in commercial products sold for personal or residential use (Carter and others, 2007). These compounds generally are associated with wastewater discharge (Kolpin and others, 2002). However, people swim and raft in Lake Tahoe, the reservoirs, and the Truckee River, so this also could be a source. Most detections of these compounds were in the autumn and winter, so a recreational source is a less likely source of these compounds than wastewater discharge.

\section{Potential Effects on Human Health}

Concentrations in source- and finished-water generally were less than $0.1 \mu \mathrm{g} / \mathrm{L}$ and always less than human-health benchmarks, which are available for about one-half of the compounds. On the basis of this screening-level assessment, adverse effects to human health are expected to be negligible (subject to limitations of available humanhealth benchmarks, see inset "Human-Health Benchmarks Used in This Assessment").

Although the type of conventional water treatment used by this community water system (which is typical of many systems across the Nation) is not specifically designed to remove most organic compounds, concentrations generally were less than $0.1 \mu \mathrm{g} / \mathrm{L}$. For perspective, reporting limits for public drinking water commonly are set through Federal regulations at $0.5 \mu \mathrm{g} / \mathrm{L}$, and water utilities generally are not required to measure below this limit.

Concentrations of seven compounds that were detected in source and (or) finished water were greater than or equal to $0.1 \mu \mathrm{g} / \mathrm{L}$ (table 2). Compounds with concentrations greater than $0.1 \mu \mathrm{g} / \mathrm{L}$, such as toluene, were frequently detected because their physical properties allow them to persist in the environment (Zogorski and others, 2006). The three disinfection by-product compounds in the finished water with concentrations greater than $0.1 \mu \mathrm{g} / \mathrm{L}$ are expected because of disinfection with chlorine and chloramine at the water treatment plant (Krasner and others, 2006).

Sample concentrations did not exceed drinking-water standards for USEPA Maximum Contaminant Levels (MCLs) for regulated compounds (table 2) in this study. Concentrations also were less than USGS Health-Based Screening Levels (HBSLs) established for selected unregulated compounds (see inset "Human-Health Benchmarks Used in This Assessment").

The USGS screening-level assessment also identified compounds at concentrations less than, but within a factor of 10, of humanhealth benchmarks. Only three regulated compounds were detected
Human-Health Benchmarks Used in This Assessment

A screening-level assessment of the potential significance of detected compounds to human health was based on a comparison of measured concentrations to available human-health benchmarks. Specifically, concentrations of regulated compounds were compared to USEPA Maximum Contaminant Levels (MCLs), and concentrations of unregulated compounds that have USEPA published toxicity information were compared to USGS Health-Based Screening Levels (HBSLs). The HBSLs were developed in collaboration with USEPA, New Jersey Department of Environmental Protection, and Oregon Health and Science University (Toccalino and others, 2007). About one-half of the detected compounds do not have human-health benchmarks or adequate toxicity information for evaluating results in a human-health context. Human-health benchmarks are developed for individual compounds and not mixtures. The screening-level assessment provides an initial perspective on the potential importance of "man-made" organic compounds in source water; it is not a substitute for a comprehensive risk assessment, which includes many more factors, such as additional avenues of exposure.

at concentrations less than, but within a factor of 10, of the USEPA MCL. These compounds include the disinfection by-products (trihalomethanes - chloroform, bromodichloromethane, and dibromochloromethane) and the combined concentration of all three compounds (total THMs) is within a factor of 10 (table 2).

An important consideration in assessing potential effects for human health is the common occurrence of mixtures of organic compounds in source- and finished-water samples. For example, nine compounds were detected in paired source and finished water samples from the Truckee River. This is comparable to findings from eight additional community water systems sampled by the USGS (Kingsbury and others, 2008). The potential human-health effects of mixtures of co-occurring organic compounds are largely unknown and have not been extensively studied. The effect of one compound on another's toxicity may be additive, antagonistic, or synergistic. With a few exceptions for pesticides with common modes of action, humanhealth benchmarks generally are not available for specific mixtures. Continued research is needed because MCLs and other human-health benchmarks generally are based on toxicity data for individual compounds, and the effects of specific mixtures of compounds at low levels are not well understood (Carpenter and others, 2002; Kingsbury and others, 2008).

\section{Truckee River Findings in a National Context and Possible Implications}

Overall, the compounds detected most commonly in water from the Truckee River (tables 1 and 2) are among those most commonly detected in ambient stream water and groundwater across the Nation (Gilliom and others, 2006; Zogorski and others, 2006). The occurrence and concentrations of compounds in source- and finished-water samples from the Truckee River also were similar to those detected at other community water systems sampled as part of an ongoing national NAWQA investigation of rivers (Kingsbury and others, 2008). However, fewer compounds were detected in the Truckee River samples than for most other NAWQA investigations. Additionally, findings in a national context are considered preliminary because some compounds included in this study only recently have been monitored systematically in source and finished waters, including, for example, plant- or animal-derived biochemicals (such as cholesterol and 3-beta-coprostanol) and those used for personal care, such as hexahydrohexamethylcyclopentabenzopyran (HHCB). Continued research is needed to better understand sources, transport mechanisms, trends, fate in the environment, and possible linkages of these compounds to human health. 


\section{Source Water-Quality Assessments by the NAWOA Program Conducted Across the Nation}

Beginning in 2002, the USGS NAWQA Program initiated "Source Water-Quality Assessments" (SWQAs) at selected community water systems across the United States (Delzer and Hamilton,2007). The long-term goal is to complete as many as 30 SWQAs at systems that withdraw water from streams by 2012 using standard protocols and nationally consistent methods (U.S. Geological Survey, 1997-2006).

This fact sheet highlights findings from the Truckee River study, which is one of the first nine community water systems sampled. The fact sheet serves as a companion product to a USGS Data Series Report and a Scientific Investigations Report that present findings for the nine systems across the United States (Carter and others, 2007; Kingsbury and others, 2008). http://water.usgs.gov/nawqa/swqa

USGS will continue to collaborate with, and complement the work of other Federal, State, and local organizations, and to continue to communicate findings, possible implications, and future needs, including, for example:

- Increased emphasis on watershed management and source-water protection strategies to help minimize the sources and transport of compounds to source water and ultimately to finished water.

- Continued research will enhance information about toxicity in commonly occurring unregulated compounds and mixtures that are detected in source and finished water.

- Current and future monitoring and assessment of compounds not typically monitored in source water, but commonly present in finished water, which may identify or lead to the development of treatment technologies for their removal.

\section{References Cited}

Bevans, H.E., Lico, M.S., and Lawrence, S.J., 1998, Water quality in the Las Vegas Valley area and the Carson and Truckee River basins, Nevada and California, 1992-96: U.S. Geological Survey Circular 1170, 47 p., available at http://pubs.usgs.gov/circ/circ1170

Carpenter, D.O., Arcaro, K., and Spink, D.C., 2002, Understanding the human health effects of chemical mixtures: Environmental Health Perspectives, v. 110, p. 25-42.

Carter, J.M., Delzer, G.C., Kingsbury, J.A., and Hopple, J.A., 2007, Concentration data for anthropogenic organic compounds in ground water, surface water, and finished water of selected community water systems in the United States, 2002-05: U.S. Geological Survey Data Series 268, 30 p., available at http://pubs.usgs.gov/ ds/2007/268

Delzer, G.C., and Hamilton, P.A., 2007, National Water-Quality Assessment Program-Source Water-Quality Assessments: U.S. Geological Survey Fact Sheet 2007-3069, 2 p., available at http:// pubs.er.usgs.gov/usgspubs/fs/fs20073069

Gilliom, R.J., Barbash, J.E., Crawford, C.G., Hamilton, P.A., Martin, J.D., Nakagaki, Naomi, Nowell, L.H., Scott, J.C., Stackelberg, P.E., Thelin, G.P., and Wolock, D.M., 2006, The quality of our Nation's waters-Pesticides in the Nation's streams and ground water, 1992-2001: U.S. Geological Survey Circular 1291, 172 p., available at http://pubs.er.usgs.gov/usgspubs/cir/cir1291

Grady, S.J., 2002, National survey of Methyl tert-Butyl Ether and other volatile organic compounds in drinking-water sources-Results of the random survey: U.S. Geological Survey Water-Resources Investigations Report 02-4079, 85 p., available at http://sd.water. usgs.gov/nawqa/pubs/wrir/wrir02 4079.html
Kingsbury, J.A., Delzer, G.C., and Hopple, J.A., 2008, Anthropogenic organic compounds in source water of nine community water systems that withdraw from streams, 2002-05: U.S. Geological Survey Scientific Investigations Report 2008-5208, 68 p., available at http://pubs.er.usgs.gov/usgspubs/sir/sir20085208.

Kolpin, D.W., Furlong, E.T., Meyer, M.T., Thurman, E.M., Zaugg, S.D., Barber, L.B., and Buxton, H.T., 2002, Pharmaceuticals, hormones, and other organic wastewater contaminants in U.S streams, 1999-2000-A national reconnaissance: Environmental Science and Technology, v. 36, no. 6, p. 1,202-1,211.

Krasner, S.W., Weinberg, H.S., Richardson, S.D., Pastor, S.J., Chinn, R., Sclimenti, M.J., Onstad, G.D., and Thurston, A.D., Jr., 2006, Occurrence of a new generation of disinfection byproducts: Environmental Science \& Technology, v. 40, no. 23, p. 7175-7185.

Toccalino, P.L., Norman, J.E., Booth, N.L., and Zogorski, J.S., 2007, Health-Based Screening Levels - A tool for evaluating what waterquality data may mean to human health: U.S. Geological Survey, National Water-Quality Assessment Program, accessed June 5, 2008, at http://water.usgs.gov/nawqa/HBSL/.

U.S. Department of Agriculture, 2008, Agricultural Research Service (ARS), Pesticide properties database, accessed March 6, 2008, at http://www.ams.usda.gov/science/pdp/.

U.S. Environmental Protection Agency, 2007a, Setting standards for safe drinking water: U.S. Environmental Protection Agency, Office of Ground Water and Drinking Water, accessed June 1, 2007, at http://www.epa.gov/safewater/standard/setting.html

U.S. Environmental Protection Agency, 2007b, Unregulated Contaminant Monitoring Program: U.S. Environmental Protection Agency, accessed January 11, 2009, at http://www.epa.gov/ safewater/ucmr/index.html

U.S. Geological Survey, 1997-2006, National field manual for the collection of water-quality data: U.S. Geological Survey Techniques of Water-Resources Investigations, book 9, chaps. A1-A9, available at http://water.usgs.gov/owq/FieldManual/ (chapters were originally published during 1997-1999; updates and revisions are ongoing and are summarized at http://water.usgs.gov/owq/FieldManual/ mastererrata.html).

Zogorski, J.S., Carter, J.M., Ivahnenko, Tamara, Lapham, W.W., Moran, M.J., Rowe, B.L., Squillace, P.J., and Toccalino, P.L., 2006, The quality of our Nation's waters - Volatile organic compounds in the Nation's ground water and drinking-water supply wells: U.S. Geological Survey Circular 1292, 101 p., available at http://pubs. er.usgs.gov/usgspubs/cir/cir1292

\section{By Karen A. Thomas}

\section{USGS promotes public access to water-quality information}

This fact sheet, additional data and investigations reports, and other information are available on the World Wide Web at http://water.usgs.gov/ nawqa/swqa. Included at this Web site are downloadable data on organic compound occurrence, information on sampling designs and methodology, background on data analyses, and frequently asked questions.

\section{Contacts for additional information}

For more information concerning the research in this report, contact the Director, Nevada Water Science Center

U.S. Geological Survey 2730 N. Deer Run Road

Carson City, Nevada 89701

http://nevada.usgs.gov/water/

Publishing support provided by the U.S. Geological Survey Publishing Network, Tacoma Publishing Service Center 